American Journal of Qualitative Research

June 2020, Vol.4 No. 1, pp. 69-84

https://doi.org/10.29333/ajqr/8266

(C) 2020 AJQR. http://www.ajqr.org
AMERICAN

JOURNAL OF QUALTATIVE

RESEARCH

ISSN: 2576-2141

\title{
Human Rights, Conflicts, and Dislocation: The Case of Turkey in a Global Spectrum
}

\author{
Hafza Girdap ${ }^{1}$ \\ Stony Brook University
}

\begin{abstract}
The overall purpose of this study is to explore human rights ramifications in the recent context of Turkey, the forced migration journeys of intellectuals from the country after the failed coup attempt in 2016, their experiences of seeking legal status, and other immigration issues in Europe and the USA focusing on integration and adaptation issues. As a qualitative research conducted through interviews, this paper analyzes implementation of international human rights laws in Turkey by scrutinizing the political practices and their influences on the targeted individuals/groups particularly after the 2016 coup attempt. The findings in this paper will help researchers studying this specific era in Turkey's historical context in terms of human rights obtain a comprehensive insight through lived and shared experiences of persecuted people.
\end{abstract}

KEYWORDS: Turkey, Human Rights, Conflict, Dislocation, Freedom of Speech.

\section{Introduction}

One of the major accomplishments of the $20^{\text {th }}$ century has been the rise of the global human rights movement which witnessed the birth of the Universal Declaration of Human Rights as well as other international and regional human rights documents. Despite this advancement, the achievement of human rights remains an unrealized ideal for millions of people all across the globe, including in the United States.

This article begins with an introduction to the theoretical and historical foundations of human rights along with their implementation problems. Through a case study of Turkey, it will explore the structural and institutional elements of the human rights regime as well as the complexities of human rights advocacy and its practice in today's globalized world. The article will critically evaluate the main motives behind the large numbers of people fleeing Turkey in the last decade. This work will study the different ways Turkey's regime oppresses its people on grounds of freedom of expression and violation of universal human rights. Subsequently, the study will explain how people of Turkey are compelled to migrate. More precisely I will argue about the misuse of human rights issues by the current administration in Turkey through the religious and cultural discourse and the discourse of "for the continuity of the state", along with its influence on forced migration as a result of violations of basic human rights, specifically the right to freedom of

\footnotetext{
${ }^{1}$ Corresponding author; hafza.girdap@stonybrook.edu
} 
expression and speech. The discussion will go further and analyze the effects of human rights violations and forced migration on the new lives of the persecuted person(s). For this analysis, interviews will be conducted with members of Turkish communities, who have been granted asylum, pending asylum, or have been in search of different legal statuses both in different parts of Europe and in the USA. In order to answer the question of what kinds of distinct challenges an immigrant goes through in terms of survival and integration, this ethnographic research focuses on specific segments of the Turkish population, such as academics and journalists, who have fled their countries. The article explores human rights implications in the context of Turkey, the main motives behind the escapes from the country, asylum practices, and as well as other immigrant issues in the Western world concerning integration and adaptation issues.

\section{International Human Rights Regime}

Human rights, according to Universal Declaration of Human Rights, are all the rights a human being is "entitled" regardless of race, religion, sexuality, color and so forth. The rights of humans all around the world are gradually taken under protection by means of distinct conventions, declarations, and covenants. In other words, human rights have theoretically been institutionalized universally. In this section, I will first explain four international human rights treaties of which Turkey is a party state, and then discuss implications, critiques, and debates around these treaties.

End of World War II justified the formation of the international human rights movement and the Universal Declaration of Human Rights (UDHR) became the global outcome of this initiation. In other words, for the first time, fundamental human rights were universally protected by the participation of 50 countries. Explained in its 30 articles, four pillars of UDHR are dignity, liberty, equality, and brotherhood.

The International Covenant on Civil and Political Rights (ICCPR) is observed by the United Nations Human Rights Committee and controls the responsibilities and actions of party states regularly. In the preamble of the covenant, which has 53 articles, the main objective is stated as "in accordance with the Universal Declaration of Human Rights, the ideal of free human beings enjoying civil and political freedom and freedom from fear and want can only be achieved if conditions are created whereby everyone may enjoy his civil and political rights, as well as his economic, social and cultural rights".

The International Covenant of Economic, Social and Cultural Rights (ICESCR), as a multilateral treaty, is in the control of the United Nations Committee on Economic, Social and Cultural Rights. Party states of this covenant are supposed to be committed to ensure conditions where everyone may enjoy their economic, social and cultural rights, as well as his civil and political rights are in place.

Another human rights document that should be taken into consideration while studying Islam and human rights is The Cairo Declaration on Human Rights in Islam. It was adopted by the Organization of Islamic Cooperation (OIC) in 1990. Its central purpose is to provide an Islamic perspective on human rights issues, and this is precisely stated in the document. According to the declaration, Islamic community is the best in the world and human rights should be affirmed according to Islamic Sharia.

Given the fact that The Cairo Declaration is reinterpretation or "vernacularization" of international rights in the Muslim context through an Islamic discourse, the famous question remains still popular: "Is Islam compatible with democracy?" I stand by the idea that there should be a moderate way between universalism and cultural relativism, however I also believe that rewriting universal rights based on religious rules gives the regimes / governments / leaders 
justification opportunities for their own power claims. Kayaoglu (2012) criticizes The Cairo Declaration claiming that it is basically established according to sharia (Islamic law) and elaborates four main drawbacks. In this sense, the author states that the declaration is too restrictive because sharia is not compatible with free speech and civil rights. Additionally, due to the unspecified structure of sharia, Kayaoglu asserts that The Cairo Declaration is ambiguous. Furthermore, not individuals but states are empowered by the document contrasting universal human rights norms. The last point the writer emphasizes is the declaration conflicts with international human rights since the main discourse is religious and some articles reveal gender discrimination. Although Turkey is not ruled by Sharia, it is a Muslim majority country. Therefore, it would be appropriate to look into human rights in Muslim context prior to explaining the oppression and violations in Turkey. Daniel Pipes (2008), in parallel with Kayaoglu, explicitly claims Muslim majority countries are less democratic while rejecting the common idea that Islam is not compatible with democracy on the grounds of his belief that religion can evolve in a positive direction in terms of human rights. In this regard, I disagree with Kayaoglu since he points to Islam as the source of violations of human rights or undemocratization. I think he overlooks so many other actors and factors which should be considered in a contextual analysis. Pipes, just like Kayaoglu, misinterprets this point by suggesting that Islam can evolve to a democratic direction. Let me clarify my point: rather than focusing on Islam itself, contextual actors and factors need to be taken into consideration while studying human rights issues in the Muslim world; since religion, as other foundations of human rights, is doomed to be a proxy for power combat.

Through a contextual analysis I will examine international human rights norms and their implementation in regard to ongoing situations concerning the collapse of rule of law and dire human rights violations in Turkey after the following part which provides a closer insight to human rights issues in the Muslim Context.

\section{Human Rights in Muslim Context}

Discussion of human rights in the scholarship inevitably requires bringing the contextual perspective to the table. It is especially important while studying this issue in Muslim majority countries, where the role of culture in general and religion in particular is compelling to analyze. In this section, I would like to build up the foundation for my case study in which the debate of human rights is utilized and directed by the authorities through culture and religion. As an indication of this claim, the most concrete attempt of the government has been to stigmatize its dissidents as terrorists or enemies of the state by means of cultural discourse in which the existence and independence of the state have a profound status. More than 200 journalists in Turkey have been imprisoned and their press cards have been canceled with the accusation of terrorism or threatening the state's continuity. During BBC's HardTalk show, Erdogan stated "No-one is jailed because of journalism here. Just two actual journalists are in jail right now". ${ }^{2}$ As it can also be noted in the last section of the article where I discuss the interviews, Turkey is one of the many countries where Islam and the idea of state's continuity stand as an empty signifier to confer, comment and shape the discourse of human rights that is interpreted and exploited for power claim.

In consideration of my argument about the role of religion in human rights dispute, which stresses that a contextual analysis is essential to diagnose the problems and obstacles of a proper implementation of rights in Muslim contexts, it is convenient to mention Western perception of the connection between Islam and human rights. In the introduction part of Islam and Human Rights:

\footnotetext{
${ }^{2}$ President Erdogan Tells BBC: EU Wastes Turkey's Time https://www.bbc.com/news/world-europe-40577216
} 
Advancing A U.S.- Muslim Dialogue, Shireen Hunter asserts that the very basic notion within the Western thought of Muslim world has been the idea that Islam conflicts with their interests of human rights. In other words, in the eyes of the West, teachings Islam has contradictions with human rights and democracy. Scholarly debates have been carried out for decades concerning human rights issues both in the East and the West. Universality versus relativity concepts emerged through these debates which brings forward different approaches to interpret the basis, extent and applicability of human rights.

If international human rights norms are not resonant with cultural aspects of a particular context, then it becomes more complicated to articulate this discourse. In order to achieve such a resonance, the most important action is to know the context and is to understand the dominant paradigm there. In regard to universalistic aspect of human rights norms, Ann Elizabeth Mayer claims that UDHR (Universal Declaration of Human Rights), leaves some basic issues out, in spite of its global existence (Hunter, 2005). Among them are the inherent features of human rights and whether they were culturally/ideologically produced or were functions of global/regional consensus. Mayer applies the universalism and relativism concepts to explain contextual distinctions in the interpretation and application of human rights issues in the Muslim World in her piece Evolving of Human Rights. By stating that "The notion that Islam by itself blocks the acceptance of UN standards is shown to be misguided; that there are many "Islams" needs to be kept in mind", Mayer emphasizes the significance of studies that consider historical, regional and cultural contexts (Hunter, 2005). From her piece, it can also be inferred that governments disregard international law of human rights and state coercion and violations take place through domestic traditions and laws, this is the case not only in the Muslim context but also in the U.S. Correspondingly, Lawrence Davidson asserts in his essay Framing The Human Rights Discourse: The Role of Natural Localism and The Power of Paradigm (Monshipouri, 2011) that even though human rights are universal; they are acquired, interpreted and applied locally. He coined the term "natural localism" regarding this perception of locality understanding of human rights matters. One of the most compelling outcomes of "natural localism", he claims, is that governments, religious leaders, even the media can bestow, and do bestow their own interests, which also takes the situation towards a "closed information environment". Picturing the consequences of that kind of possible oppression of liberty and freedom of expression, Lawrence advises not to give up the struggle, since human rights do not descend from heaven, they are products and must be fought for. Like Davidson, Dorraj, too, points out to the universal aspect of human rights by elaborating local and cultural differences of implementation in his work Islam and Human Rights: Ideals and Practices. He discloses the potential threats of relativist idea which can be summarized as governmental misuse:

As a faith, Islam is not frozen in time and space. What Muslims have made and continue to make of Islam is historically and socially conditioned. Given this reality, our analytical gaze instead should be focused on the social and political developments and the state and its exercise and abuse of power. As the focus of power and the embodiment of the monopoly of the force, the state can be potentially a protector of human rights or its violator (Monshipouri, 2011).

Women's rights and their position in the Turkish society, for instance, have been a very powerful proxy for the authority within human rights debate in Turkey. This debate has been manipulated by the elite powers through interpreting Islamic and cultural norms according to 
political interests. As AKP (Justice and Development Party--current government under the leadership of Erdogan) consolidated its strength in the 2011 elections, one of the very first steps regarding women's roles was changing the name of the "Ministry of Women and Family" into "Ministry of Family and Social Politics". By doing so, women were restricted to their families with traditional roles as mothers and wives.

In correspondence with the discussion of Islam and its compatibility with human rights matters, Khaled Abou El Fadi proposes that it is religious articulation through what we should approach to the elimination of religious barriers against human rights issues in the Islamic context. In A Distinctly Islamic View of Human Rights: Does It Exist And is It Compatible with The Universal Declaration of Human Rights? he adds "textual versus contextual" interpretations to "universality versus relativity" debate (Hunter, 2005). By this, he means that sacred sources, the Quran and hadith in the Muslim World, should be discussed with the idea that they are dynamic and there is a "creative process" in formulating them. Affirming the sanctity of human life notion in the Quran, El Fadi claims that Islam has the seeds for the human rights matters and they ought to be harvested though universal norms (Hunter, 2005).

To conclude this part, I propose that Rane, Dorraj and El Fadi mostly appeal to Islamic terms and their resonance in the Islamic context. By emphasizing the dynamic aspect of religion, they claim that the objections against certain human rights issues within the Islamic jurisprudence can be challenged. The works of Mayer and Lawrence, from similar standpoints, draw attention to the detrimental outcomes of relativist idea of human rights. For the sake of their own power, local interpretation of human rights norms by governments, leaders, etc. would lead to authoritarian approaches and might cause oppression through a so-called legitimate discourse of Islam. Within the part that Turkey's case is discussed, I will disclose the shift from democracy towards authoritarianism, which is a reflection of what these authors claim above. I have to mention, my take on this is neither defending solely the universalistic approach nor strictly rejecting relativist idea. As an academic and an activist, I advocate for establishing cultural or contextual resonance with universal norms of human rights. More precisely, this can be interpreted as employing universality through the discourse of specific contexts' cultures, religion and politics.

\section{Research Methods and Case Study: Oppression of Freedom of Expression and Persecution of Intellectuals}

This paper draws on a case study of intellectuals in Turkey who have been exposed to purge and persecution which started before and continued intensively after the failed coup attempt on July 15, 2016. This particular group has undergone drastic outcomes of oppression of freedom of expression by being dismissed from their jobs, losing all the platforms they could speak out, being in danger to get jailed and so on. As a result, they were forced to make a choice: (1) stay in Turkey and face these circumstances or (2) leave the country to an unknown future in terms of economy, occupation and living standards. For this study, intellectuals among the targeted group were chosen as the case-study group, since they were among the most affected and suffered citizens of the tremendous decline in freedom of expression. Moreover, speaking out against this kind of oppression brought the accusation of terrorism for many academics and journalists, which lead to forced migration.

Narratives and findings in this article were deduced from 10 video-recorded interviews. Furthermore, my own observation within the Turkish communities across the U.S. and also interactions with aforesaid intellectual groups in European countries were also added as insights concerning their experiences. The interviewees were a diverse group of intellectuals, in the ways 
that they left Turkey, legal statuses, occupations, gender and age. These distinct features of the interviewees were helpful when analyzing the implications of not only human rights violations in the home country, but also adaptation and integration issues in their new settlements. According to the confidentiality agreement, initials of the participants are used in this article. However, some of the journalists prefer to be heard with their names concerning their wish to voice the ongoing situation in Turkey, so I quoted some of their words with their names.

\title{
Turkey Case
}

\section{Human Rights in Turkey}

The excessive power that is claimed through mostly for "the sake of the state's continuity" gives the rulers a legitimized authority for oppression and eventually mass human rights violations. President Erdogan made his attitude in this matter very clear by these words: "Democracy is like a train, you get off once you have reached your destination". ${ }^{3}$ After the failed coup attempt, Turkish state declared a huge amount of Emergency Decree Laws that justified the crackdown on critics. In Turkey's Post-Coup Purification Process: Collective Dismissals of Public Servants Under the European Convention on Human Rights, Ruys and Turkey focus on the collective dismissals of public servants after the failed coup attempt in July 2016 in Turkey. While examining the problem, the authors employ the European Convention on Human Rights by pinpointing specifically to Article 6 (right to fair trial), Article 8 (right to privacy) and Article 13 (right to an effective remedy). Through a comparison with the European Court's case-law on lustration proceedings, authors showcase the scope of Turkish purge and the failure of reconciliation of this purge with the obligations under the ECHR. Although Turkey attempts to justify the dismissals by means of Emergency Decrees, there are still violations of both domestic and international laws in terms of human rights issues. Here, I would like to deliberate the issue of OHAL (Turkish acronym for State of Emergency) through which Turkish government has conducted mass purges.

Cinar and Sirin, in Turkey's Human Rights Agenda, explain Turkey's derogation from those conventions on a legal foundation. An emphasis on the scope of the dismissals and purge by means of OHAL, draws a clear conclusion which approves the fact that not a single group or an ideology, but all the opposing individuals are targeted by the Turkish Government. One of the journalist participants, C.G., pictured this situation by saying:

\begin{abstract}
All the dissident journalists are labeled as terrorists. The Turkish state, without needing any evidence and even any legal requirements, can claim a group of people as terrorists. Once it was Kurdish community that was targeted but now Kurdish people, people from the Gulen movement, Alavis, Armenians, CHP (Republican People's Party) and HDP (People's Democratic Party) supporters are being stigmatized as terrorists or the enemies of the state.
\end{abstract}

It is apparent that Turkey has never been on a good level at ensuring human rights in its history. Although the power distribution has changed the identities of the oppressor and the oppressed, presence of violations continued. Hayko Bagdat, one of the journalist interviewees, pointed on the Kurdish- Turkish conflict that has always inextricably intertwined with all presiding

\footnotetext{
${ }^{3}$ Getting Off the Train

https://www.economist.com/special-report/2016/02/04/getting-off-the-train
} 
governments. Similarly, violations of rights of minorities such as the Armenian community have been ongoing since the expulsion of more than one million Armenians in the Ottoman Era. Regarding Bagdat's point in this regard, Alavis, who have been excluded from higher ranked positions in governmental institutions, should also be reminded here. Bagdat also highlighted the headscarf ban issue that lasted until 2013 to emphasize the violations of religious rights. As it is discussed in "Turkey's Human Rights Agenda" shifting nature of political progress demonstrates how the country has undergone transitions of democracy back and forward (Lafer, 2014). According to Cinar and Sirin's and Faltis article, Kurdish population has always been among the oppressed in terms of their rights based on international treaties. Especially in 1990s enforced disappearances, mass detentions and even killings of Kurdish people in the southeast part of Turkey are allegedly linked to covert organizations of military forces under the OHAL (state of emergency) system. However, it is significant to stress again that the extent of the targeted dissidents of the government regardless of their beliefs, ideologies, political views has never been so ample.

In accordance with the literature review in this section, I addressed the human rights issues in Turkey by emphasizing the departure from obligations to international treaties and conventions. Turkey is guilty of committing human rights crimes on all accounts according to these treaties. Moreover, given the lack of independence of the judiciary system, Turkish people do not have any opportunities to reclaim their rights. S.D., one of the academic participants from the USA, said "I was in another country waiting for the approval of the U.S. visa--not sure if I will have it--when I heard an arrest warrant was issued for me. I searched up for the Bakirkoy Prison in case the U.S. didn't issue the visa and I might be deported from that country. It was devastating, it was depressing." Dismissals, mass arrests, enforced disappearances, property seizures, passport confiscations, closure of thousands of institutions and violations of universal human rights make survival in Turkey almost impossible, the consequences urge dissidents to leave the country either in legal or in illegal ways.

\section{A Shift to Autocracy in Turkey}

Given the fact that this article focuses on the experiences of academics and journalists, who can be asserted to be the greatest portion of the intellectuals in a country, it is pertinent to shed light upon violation of the freedom of expression right. In their article Democracy in Turkey Press Freedom and Corruption, Tomgusehan and Kececi examine the violation of the right to freedom of expression through press freedom since the press plays a crucial role to sustain democracy. By emphasizing the negative impact of corruption on the sustainability of democracy, the authors analyze civil and political rights within a corrupt system of politics and judiciary. Through empirical research, their study concludes with the fact that people of Turkey do not believe there is freedom of expression (82\%) and democracy (82\%). The results gathered from participants in my own research affirm this data. All participants stated they left Turkey because of the lack of freedom of expression and collapse of democracy. A very concrete relation exists between the lack of freedom of expression (press freedom) and corruption which leads to collapse of rule of law. An eventual outcome of this mutual relation is excessive power within the administration that also leads to injustice, "civil death", economic and social troubles. This case study demonstrates these factors also ultimately lead people of intellectualism to forced migration. As an example of unlawful enforcement journalist, B.B. told about the police raids during which people are convicted because of possession of one-dollar bills in their houses. (Possession of one dollar bills is allegedly linked to be a member of Gulen movement and it is claimed that "serial-number letters on the 
banknotes are used as code within the movement"4) Academic L.A. mentioned the weariness he felt because of the fear he experienced back in Turkey while commuting by public transportation and said:

Because of the emergency state the police was doing ID checks at the train stations and bus stops. I had to commute to give private classes in different areas of Istanbul. As a dismissed academic and a defined dissident, it was a mortal fear to see the police and to live like in a purgatory. It was impossible to survive in such anxiety! We had to leave!

States, under international human rights laws, are obliged to ensure that their citizens enjoy human rights and to protect them against any violations and abuses of these rights. Nevertheless, the current administration in Turkey not only fails to fulfill this duty and denies them but also goes beyond and persecutes the citizens who seek and favor basic rights such as the right to freedom of speech and expression. For that matter, those who criticize the government and people in power have been silenced and ultimately punished with prison sentences for almost a decade specifically since the coup attempt in 2016. The dismissals of 130,000+ public servants, shutdown of 200+ media outlets and 15 universities, imprisonment of more than 150 journalists--legitimized through emergency decrees declared right after the aforesaid failed coup--attest the political oppression in Turkey. (Amnesty International, 2018b). In order to emphasize why freedom of speech is eminently important I would like to quote the beginning sentence of Dogan's An Overview of Academic Freedom in Turkey: Re-Thinking Theory and Praxis: "Throughout history, intellectuals always play a crucial role in influencing and changing society". The attitude of an authoritarian / totalitarian government is claimed in this work to be anti-intellectual. Dogan examines the academic freedom issue in Turkey through a specific group called "Academics for Peace" and the petition they work for. Drawing an analogy between Frankfurt School, whose members flee from the Third Reich in Germany and the migration of Turkish academics mostly after 2016, the author pictures the atmosphere in Turkey where the authoritarian regime oppresses academics who are supposedly the voice of freedom of expression. I inferred a very important question from the paper in which the difference and unity of theory and practices of freedom of expression are also explained: "For whose good should the academics pursue academic goals?". The Turkish state's approach to this issue is revealed in the Higher Education Legislation as follows:

Universities, members of the teaching staff and their assistants may freely engage in all kinds of scientific research and publication. However, this shall not include the liberty to engage in activities against the existence and independence of the State, and against the integrity and indivisibility of the nation and the country. ${ }^{5}$

I assert that a state which claims itself above its citizens shifts inevitably to authoritarianism and persecutes its own intellectuals by taking the right to freedom of expression away.

Along with the academic works I analyze in this paper, human rights reports of governmental and nongovernmental organizations also confirm the extent of violations in Turkey

\footnotetext{
${ }^{4}$ Turkey: Feto's 'One-dollar Bill' Mystery Solved

https://www.aa.com.tr/en/todays-headlines/turkey-fetos-one-dollar-bill-mystery-solved/614338

${ }^{5}$ Yuksekogretim Kanunu

https://www.mevzuat.gov.tr/MevzuatMetin/1.5.2547.pdf
} 
carried out by the authorities. The U.S. State Department's Turkey 2018 Human Rights Report highlights the grave human rights violations in Turkey through the medium of statistical data and case samples. Stating that Turkey "experienced significant political changes" in 2018, the document reports that "state of emergency had far-reaching effects on the country's society and institutions, restricting the exercise of many fundamental freedoms". According to the report, more than 130,000 civil servants were dismissed or suspended from three jobs, more than 80,000 citizens were arrested or imprisoned, and 1,500 NGOs were shut down for alleged ties to Gulen (Hizmet) movement. It also indicated in the report that the "hundreds of incarcerations" are executed in relation to freedom of expression. More precisely, criticizing the government or being affiliated with certain beliefs and views are among the reasons to be arrested. Besides arbitrary detentions and arrests of any opponents; torture, "suspicious deaths" in police custody, and enforced disappearances are among the grave human rights violations in Turkey in the aftermath of the failed coup attempt in 2016 (Aydin \& Avincan, 2020).

As a transition to the discussion of the reasons and outcomes of escapes from Turkey for a better and freer life, it is pertinent to incorporate significant remarks from Journalists and Writers Foundation's 2018 report Escaping The Witch Hunt [The Right to Leave] from Turkey \& Around the World into this section. Outlining the right to movement and the violations of this right particularly in Turkey regarding the confiscations of passports, the report examines abduction cases abroad operated by the covert agents of Turkish government. It is asserted that as of April 2018, 38 people allegedly affiliated with the Hizmet Movement were abducted both in Turkey and on the soils of foreign countries. These indications put forward the fact that it is not only integration or adaptation issues in their new lives for the dissidents who flee the country but also safety concerns. A journalist participant, C.G., pointed out this fact through these words: "Before coming to Germany I stayed in Greece for a while. But knowing that an unofficial assassination team was tracking well-known dissidents to either murder or abduct, I needed to leave Greece as soon as possible." Correspondingly, Hayko Bagdat stated that he cannot work as an Uber driver because of the safety concerns even in Germany since pro government Turkish nationals are conducting violent acts against dissidents.

\section{Fleeing Conflict / Migrating to Freedom}

The main motivation behind the escape of all of the participants whom I interviewed within this research was to seek freedom. Freedom, not only in the sense of avoiding prison, but also living and speaking freely. In other words, all the academics and journalists I interviewed wished to be able to speak out against oppression and persecution taking place in Turkey. In this sense, they left the country either just before or just after July 2016. The political atmosphere within the period between corruption probe against the high-level government officers including ministers and Erdogan himself in December 2013 and failed coup attempt in July 2016 can be said as a significant determiner in the lives of the subjects of this research. Given the scope of ongoing arbitrary investigations against dissents of the government, it was not secure to survive in those circumstances for the academics and journalists who need the loudest voice, namely freedom of expression.

According to the U.S. State Department's Turkey 2018 Human Rights Report, grave human rights violations in Turkey have been conducted by the Turkish authorities. It is also reported that "respect for the integrity of the person" has been violated as a result of arbitrary detentions, enforced disappearances, torture, denial of the fair trial especially in the aftermath of coup attempt in 2016. By departing from the obligations to international treaties and conventions, Turkey is 
apparently committing human rights crimes on almost all accounts. Moreover, given the lack of independence of the judiciary system Turkish people do not have any opportunities to reclaim their rights. Dismissals, mass arrests, enforced disappearances, property seizures, passport confiscations, closure of thousands of institutions and violations of universal human rights urge dissidents to leave the country either in legal or illegal ways. In accordance with the above said international human rights norms, one of the questions I asked the participants was to describe human rights violations in Turkey both in general and also in particular from their own perspective given the current conflict. The common ground about the current situation revealed among their responses was that rule of law and the right to fair trials are not ensured. One of the academics elaborated this status with the following words: "Normally the legal process is that the guilt is proven, and you get convicted but nowadays in Turkey you get convicted and are asked to prove innocent. There is no fair trial, there is no chance to have the right for defending yourself'. Another participant stated that almost all their rights were taken away since they were claimed to be criminals and ultimately they were "set to zero" (I preferred being loyal to this term which is very common in today's Turkey within the persecution debate) so that bank accounts, properties and passports were confiscated.

A.Y., a journalist participant, depicted the situation in the judiciary system, after the failed coup attempt, to be upside down. She said "Basically the court has to find the truth, however, in today's Turkey you are told to be criminal and asked to approve that you are not! This violates the essential norm which declares that everyone is innocent until proven guilty." Furthermore, it was not only themselves who were affected by the oppression and eventual persecution, but also their family members were threatened in many ways. The wife of one of the journalists I interviewed was dismissed from her job because of her husband. Apparently, the international principle of individuality of criminal responsibility has also been violated.

Besides their personal experiences of human rights violations, participants also expressed their ideas on the general condition in Turkey. The most striking issue that they all agreed was that Turkey has never been stated in a good scale in terms of human rights. "Rights of minorities and expats have always been neglected" asserted all of the participants. One of the journalists in this study said that "There has always been an 'otherizing' issue in the historical context of Turkey. The phrase 'How happy is the one who says I am a Turk!' is a motto that has been adopted by the majority of the society as well as the state. Additionally, 'sacred state' concept and religious discourse have always been the most effective proxies to legitimize state's deeds - both legal and illegal. In this regard, if the state stigmatizes a specific individual or group as convicted, even as terrorists, then a huge part of the society agrees without any questions." Social discrimination is one of the agonizing consequences of this kind of stigmatization in which society and state collaborate in both tangible and intangible ways. Purged people cannot find new jobs because their dismissals are registered and ultimately employers do not want/dare to hire them. An academic participant, S.D., stated "All our rights were taken away. We were being convicted in the beginning without any evidence or even indictment. We became a huge zero! All we faced was unfair trials, blocked bank accounts, seizure of our properties, obstacles to work anywhere! I mean we had no right to anything." Even the kids of those face harsh challenges at school by their peers and/or teachers by being labeled as terrorists. In addition to these traumatic experiences, a discourse which lets others capture properties of stigmatized people as booties is highly predominant in the Turkish society. Metin Balkanlioglu, a religious leader, declared in a speech he gave during a rally after the coup attempt that the properties of FETO would be "spoils of war". ${ }^{6}$ Feeling encouraged through such an exorbitant discourse, a municipality employee posted a message on the social media

\footnotetext{
${ }^{6}$ Balkanlığlu: Fetö'nün Ganimetlerini Tepe Tepe Kullanın https://www.abcgazetesi.com/guncel/balkanlioglu-fetonun-ganimetlerini-tepe-tepe-kullanin-24661 h/haber-24661
} 
claiming that "the wives and daughters of naysayers in the referendum were 'halal' for 'yes' voters as 'spoils of war". 7

In response to my question about the human rights issues from their perspectives, Hayko Bagdat, an Armenian journalist born and raised in Turkey, pointed out that human rights problems have been a hundred-year-experience for Armenian people as a minority community since the Ottoman Era. He also stated that as a journalist speaking up about headscarf issues as well as Kurdish conflict and the murder of Hrant Dink (an Armenian journalist who was assassinated in Istanbul in 2007) he has always been a target for and demonized by the Turkish state. ${ }^{8}$ As mentioned earlier in this paper, the government has targeted certain individuals and groups who are dissidents by demonizing propaganda and conclusively created discrimination against them that has been confirmed by the society. A similar opinion was indicated by an expat academic that even the lowest ranked officials want to make advantage of power they hold to dehumanize. As a reason she set forth the claim that this kind of attitude might be the reflection of their oppressed feelings over people they think they have authority as well as the propaganda of the state. Her experience of persecution as an expat was to be denied renewal of the employment authorization and asked to leave the country in two weeks just because she worked for a Gulen movement affiliated university. She portrayed her case as: "I was working on a project, there were lots of experiments in the lab and they were seized. I can say that I had to leave when my career was at its climax. The cells that we were experimenting were seized and wasted. Nobody continued the research, the government cut the electricity, and everything was wasted. Isn't this enmity of science, knowledge?" Another participant used the Nazi analogy to describe the human rights violations in Turkey in terms of the extent of the people affected, since the scope is too wide when compared to the other periods in the historical context of Turkey. She drew attention to the fact that this time it is Kurdish community, minorities, same faith and ideology groups as the government that have been oppressed, persecuted, purged, discriminated and demonized.

Hence, leaving/fleeing the country became an inevitable consequence of this persecution for the intellectuals I interviewed, who felt it was no longer possible to survive freely in Turkey. However, as the actors of an enforced migration they have faced critical challenges within their resettlements. The interviewees in this study are from either a European country or the USA so their experiences reflect the conditions in these contexts. Among the most considerable challenges they emphasized were language barrier, financial issues and professional credentials. A journalist participant described the hardest situation for him as:

Your position as a dad is put in a difficult situation, you cannot help your kid at school since you do not know the language, or you cannot provide the same things as before since you do not have enough financial opportunities. I feel I am not enough as a dad!

He also added that he could not do his job because he did not speak or understood the language in their new country. A colleague of him expressed similar thoughts that people migrate with their lifetime savings and it is about to finish. "Even though the host state provides funding for the refugees it is still hard to survive because "this is exile" he said. An academic depicted the most challenging issue for her, while integrating to a new life in a foreign country as being

\footnotetext{
${ }^{7}$ Erdoğan Gov't Turns to Rape as a Political Weapon in Turkey https://stockholmcf.org/commentary-erdogan-govt-turns-to-rape-as-a-political-weapon-in-turkey/

${ }^{8}$ Hayko Bagdat is one of the participants that approved to be cited explicitly as I mentioned in the methodology part above.
} 
unemployed, losing everything such as title, position and career. She stated that "Being an academic did not just mean having a job with a salary, it meant more to me: teaching, being satisfied with learning and teaching; so, losing all of them was hard for me. It caused a huge blank page in the very beginning of a new life." To explain the reason for this kind of start from the scratch as an academic in the USA, she categorized immigrant academics into three groups as those with degrees from Turkey who know English, those with degrees from Turkey who do not know English and finally those with degrees from a developed country like the U.S. who know English. Being in the first group made it hard for her to get a position since showing her previous experience was not satisfying enough for U.S. institutions. A journalist participant portrayed her case similarly by saying that "It is not culture or language that is really challenging for me but finding a job, not being able to get involved in the social life and not knowing what to do as the next step. I frequently feel that my life has been ruined like thousands of others." She stressed that legal status is important to have a working permit or to be eligible for health services and since it takes longer time to process asylum applications in the USA, immigrants like her who left everything behind and lost almost all inherent rights of a regular citizen have been undergoing traumas. As an asylee in Germany, a male journalist participant suggested that most of the immigrants coming from conflict zones are sophisticated and highly skilled, so being a journalist is not an advantage. Also, the residency regulations for refugees make it hard to live and work in vivid locations for journalism. When I asked if there were any organizations that helped them adapt to their new places concerning their professions, the prevailing response was that even if there were funds it was not easy to get granted as refugees because of the overwhelming paperwork or bureaucracy; moreover they were not sustainable supports. C.G., a journalist participant, explained this situation as:

There are funds but with a refugee status it is not easy to be granted for these funds or support. Also, we observe a negative perception towards refugees in Europe especially since 2015. Some prominent figures are lucky not to be exposed to this prejudice and discrimination, but we are not.

Another remarkable issue I encountered within this research is that they still feel they have to be the voice of their colleagues back in Turkey who are either incarcerated or living fearfully with the possibility of a sudden arrest. Especially all of the journalist participants speak out through the medium of the social media or the websites and online journalism against the oppression and human rights violations in Turkey. One of the participants manifested that "Whatever it takes it is imperative that we speak out for jailed journalists in Turkey. We must use and I do use all the means such as online opportunities to do this." Hayko Bagdat says that he knows people who have worse conditions and he is trying to help them even though he has been experiencing pretty harsh conditions himself.

The last matter I discussed with the participants in this research is the question of identity. I was thinking I would have considerably distinct responses, but the answers were similar to some extent. The very common point is that the participants feel deeply disappointed by the Turkish state and the society. In this regard they identify themselves with their professions and occupations rather than cultural and national bounds or elements. Instead of sticking to a sentiment of nation they prefer to explain themselves as "good people", "global citizens", "exiled journalists/academics", "Muslim women", "democrats" and "successfully integrated to the common ground of the new culture they are currently living in". S.A., a journalist participant, admitted that she was so angry and deeply heartbroken that she not only quitted patriotic feelings 
for her own country but also lost trust in her own fellow citizens since they either supported or kept silent about such a huge persecution against the intellectuals of Turkey. For this reason, S.A. defined herself as "exiled journalist". One of the responses to the identity question was quite striking. L.A., an academic interviewee, told me that he did not feel connected to Turkey, but to culture and traditions and suggested that he could convey them everywhere he went. "It does not necessarily have to be in Turkey to feel connected to my own culture. Moreover, we can blend our cultural values with the new ones in our new home (read: resettlement)" L.A. said. Another academic, M.C., similarly, identified himself belonging to his new country and added that he, hence forth, devoted himself to contribute to this place. M.C., also marked that even if Turkish authorities would admit the persecution and human rights violations they carried out against thousands of people and declare an official apology he would not want to go back to Turkey. My inference from the responses of the interviewees happened to be that a combination of resentment and disappointment that all the participants felt generated their identification terms.

In conclusion, components which are influential on the immigrants' new lives are mutually dependent. In other words; factors such as economic, legal and social, interact while the participants integrate to the resettlements. The challenges and barriers that the participants expressed as the most significant ones for the pursuit of a previous career path were language barrier, lack of financial resources and credentials issues such as certification or foreign university degrees. Ultimately this interaction of different components, both before and after the enforced migration, result in psychological issues. Journalist B.C. expressed his feeling of incapability as a father with these words:

I cannot help my kid with school issues since I do not know the language, or I cannot provide everything my family needs since I do not have enough financial opportunities. Ifeel inadequate and this causes devastation! Once I was having a good career and I could do whatever I was supposed to, now the circumstances put me into a position in which I feel stuck!

Given the tense circumstances during the legal status processes, aspects of immigrants' lives and also uncertainties in terms of employment; the participants seem to have been going through anxious phases. However, since they, as the intellectuals of their home country, feel obliged to fight for freedom of their colleagues and other fellow citizens who are still being oppressed, the participants I interviewed for this study demonstrate strength rather than devastation. Journalist C.G.'s remarks illustrate this complicated case precisely: "Most of the immigrants here in Germany, coming from conflict zones, are sophisticated and highly skilled; so being a journalist is not an advantage for me. And also, the residency conditions and policies for refugees make it hard to live and work in vivid locations for journalism. But whatever it takes we need the urgency to speak out for jailed journalists in Turkey. We use all the means such as online opportunities to do this." An academic interviewee, M.C., recalled an incident he experienced with his 8-year-old son in relation to legal status issues we talked about. He said his son once asked what their contingency plan was if they denied residency in their resettlement. As legal status is somehow linked to the idea and feeling of belonging and eventually a settled life, it can be read from this conversation that not only adults, but also minor family members are affected and go through anxiety problems.

\section{Conclusion}


I argued, throughout this article, that the misuse/misinterpretations of human rights norms (employing different discourses for the sake of power claim) lead to more authoritarian regimes and ultimately to the choice of whether to stay in the country and be exposed to a civil death or forced migration to freer countries. That is; political powers, as seen in the Turkey case, exploit the human rights issues through their own discourses such as religion and culture which conform societal priorities. As a result of this, not only more power is claimed but also authoritarian actions are justified and ultimately authorities obtain a legitimized right to oppress the opposing ideas and actions. The possession of such an excessive and suppressing power pushes intellectuals and those who demand freedom of expression and speech to crossroads where they have to choose either to stay in their homeland and submit to circumstances they are exposed to or to leave their homelands and giving up all they have such as their careers, jobs, belongings, properties and most importantly beloved ones.

My contribution to the previous studies is to showcase individual and concrete samples and also to reflect insights from the field by weaving these experiences with the human rights literature discussed in this paper. In this way, by displaying challenges and barriers experienced and expressed by the participants--as sample cases representing communities--local governments and private organizations would have the opportunity to help newcomers deal with those challenges and barriers and to take actions for creating integration programs and policies in the academy and in the world of media. For future studies, the psychological aspects of forced migration and adaptation to resettlements could be discussed as an analysis of violations of human rights and the influence of this issue on the migration studies so that aforesaid programs and policies could be expanded with rehabilitation purposes.

\section{Biographical Note}

Having her BA and MA degrees from the field of English Language and Literature Hafza Girdap is interested in analyzing the lives of Muslim women regarding the challenges they face within their own cultures, before, during and after conflicts, specifically political conflicts. Her research focuses on self-identification, gendered representation and reshaping of Muslim women, originated in Islamic cultures but resettled in Western cultures by the agency of an intersectional framework. Outside the academy she is currently working for an NGO called Advocates of Silenced Turkey (AST) to stand against human rights violations ongoing in Turkey in particular.

\section{References}

Advocates of Silenced Turkey. (2019). Erdogan's crackdown at a glance. Retrieved from https://silencedturkey.org/erdogans-crackdown-at-a-glance.

Aksoy, E. (2016, July 23). Turkey: Feto's 'one-dollar bill' mystery solved. Retrieved from https://aa.com.tr/en/todays-headlines/turkey-fetos-one-dollar-bill-mystery-solved/614338.

Amnesty International. (2018a). Amnesty international's report 2017/18: The state of world's human rights. Retrieved from https://amnesty.org/download/Documents/POL1067002018ENGLISH.PDF.

Amnesty International. (2018b). Purge beyond return. Retrieved from https://amnesty.lu/uploads/media/PURGED_BEYOND_RETURN_TURKEY.PDF.

Aydin, H., \& Avincan, K. (2020). Intellectual crimes and serious violation of human rights in Turkey: a narrative inquiry. The International Journal of Human Rights, 1-29. https://doi.org/10.1080/13642987.2020.1713108 
Balkanlıŏlu: FETO'nün ganimetlerini tepe tepe kullanın. (2016, August 9). ABC Gazetesi. Retrieved from https://abcgazetesi.com/guncel/balkanlioglu-fetonun-ganimetlerini-tepetepe-kullanin-24661h/haber-24661.

Bozkurt, A. (2018, June 17). Erdoğan gov't turns to rape as a political weapon in Turkey. Retrieved from https://stockholmcf.org/commentary-erdogan-govt-turns-to-rape-as-a-politicalweapon-in- turkey/.

Çinar, Ö. H., \& Şirin, T. (2017). Turkey’s human rights agenda. Research Turkey, 2(2), 133-143. https://doi:10.1080/23760818.2017.1350354.

Czaika, M., \& Haas, H. (2014). The globalization of migration: Has the world become more migratory? International Migration Review, 2, 283-323.

Dogan, S. (2017). An overview of academic freedom in Turkey: Re-thinking theory and praxis. Interdisciplinary Political Studies, 1. https:// doi:10.1285/i20398573v3n1p109.

Ehrkamp, P. (2005). Placing identities: Transnational practices and local attachments of Turkish immigrants in Germany. Journal of Ethnic \& Migration Studies, 31(2), 345-364. https://doi:10.1080/1369183042000339963.

Faltis, C. (2014). Toward a Race Radical Vision of Bilingual Education for Kurdish Users in Turkey: A Commentary. Journal of Ethnic and Cultural Studies, 1(1), 1-5.

Getting off the train. (2016, February 4). The Economist. Retrieved February 1, 2020 from https://www.economist.com/special-report/2016/02/04/getting-off-the-train.

Human Rights Watch. (2019). Country summary: Turkey. Retrieved from https://hrw.org/sites/default/files/turkey_pdf.pdf.

Hunter, S. (Ed). (2005). Islam and human Rights: Advancing a U.S.-Muslim dialogue. Washington, D.C.: The CSIS Press.

Journalists and Writers Foundation. (2018). Escaping the witch hunt [the right to leave] from Turkey and around the world. Retrieved from https://jwf.org/jwf/wpcontent/uploads/2018/05/Escaping-the-Witch-Hunt-from-Turkey-and-Around-the-WorldJWF-Report-April-2018.pdf.

Kayaoğlu, T. (2012). It's ime to revise the Cairo declaration of human rights in Islam. The Brookings Institution. Retrieved from https://brookings.edu/opinions/its-time-to-revisethe-cairo-declaration-of-human-rights-in-islam/

Lafer, S. (2014). Democratic Design for the Humanization of Education. Journal of Ethnic and Cultural Studies, 1(1), 6-12.

Mahmood, M. (Ed). (2011). Human rights in the Middle East: Frameworks, goals, and strategies. New York, NY: Palgrave MacMillan.

Mecellem, J. G. (Ed). (2018). Human rights trials in an era of democratic stagnation: The case of Turkey. Law \& Social Inquiry, 43(1), 119-151. https://doi:10.1111/lsi.12260.

Pieterse, J. N. (2000). Globalization and human integration: We are all migrants. Futures, 32, 385 398.

Pipes, D. (2008). A Democratic Islam?. Jerusalem Post. Retrieved from https://danielpipes.org/5517/a-democratic-islam.

President Erdogan tells BBC: EU wastes Turkey's time. (2017, 12 July). BBC. Retrieved February 15, 2020, from https://bbc.com/news/world-europe-40577216.

Ruys, T., \& Turkut, E. (2018). Turkey's post-coup purification process: Collective dismissals of public servants under the European convention on human rights. Human Rights Law Review, 3, 1-12. 
Schick, M., Zumwald, A., Knopfli, B., Nickerson, A., Bryant, R. A., Schnyder, U., Muller, J., \& Morina, N. (2016). Challenging future, challenging past: The relationship of social integration and psychological impairment in traumatized refugees. European Journal of Psychotraumatology 7(1), 12-26.

The Organization of Islamic Cooperation. (1990). The Cairo declaration on human rights in Islam. Retrieved from https://oiciphrc.org/en/data/docs/legal_instruments/OIC_HRRIT/571230.pdf.

The United Nations. (1948). Universal declaration of human rights. Retrieved from https://www.ohchr.org/EN/UDHR/Pages/UDHRIndex.aspx.

The United Nations. (1966). International covenant on civil and political rights. Retrieved from https://www.ohchr.org/en/professionalinterest/pages/ccpr.aspx.

The United Nations. (1966). International covenant on economic, social and cultural rights. Retrieved from https://www.ohchr.org/en/professionalinterest/pages/cescr.aspx.

Tomgusehan, T., \& Kececi, G. (2018). Democracy in Turkey press freedom and corruption. Revista de Cercetare Si Interventie Sociala, 63, 254-267.

United States State Department. (2018). Turkey 2018 human rights report. Retrieved from https://state.gov/wp-content/uploads/2019/03/TURKEY-2018-HUMAN-RIGHTS-

REPORT.pdf.

Wingens, M., Windzio, M., De Valk, H., \& Aybek, C. (Eds.). (2011). A life-course perspective on migration and integration. New York, NY: Springer.

Yuksekogretim Kurumu. (1981). Yuksekogretim kanunu. Retrieved from https://www.mevzuat.gov.tr/MevzuatMetin/1.5.2547.pdf.

Manuscript received December 20, 2019

Final revision received April 25, 2020

Accepted May 13, 2020 